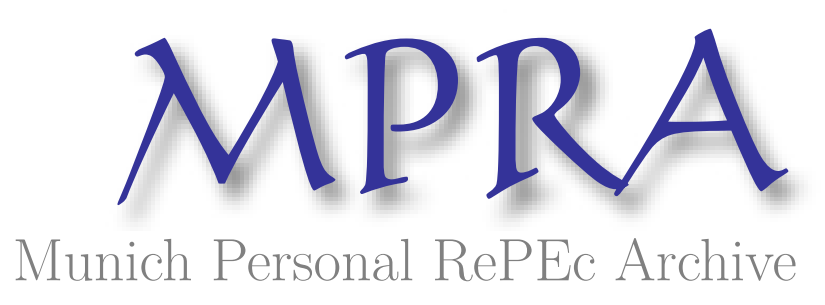

\title{
Small Enterprises and the Crisis in Indian Development
}

\author{
Tyabji, Nasir
}

July 1984

Online at https://mpra.ub.uni-muenchen.de/65459/

MPRA Paper No. 65459, posted 12 Jul 2015 22:55 UTC 


\section{Small Enterprises and the Crisis in Indian Development}

THE GOVERNMENT OF INDIA claims that it has supported the development of small enterprises, both through the creation of specific organisations which provide technical and organisational aid and through financial provisions for them in the various five year plans. To understand fully the basis and accuracy of these claims, it is important to appreciate the economic aud political background within which the Government's aid programmes were initiated. This will also allow us to understand the genesis of the Government's conception of small enterprises.

It is a widely held view that planning in India consists essentially of five year plans, which are in the nature of technical exercises. In fact, the planning process should correctly be seen as a much broader and as an emphatically political process. ${ }^{1}$ The crucial aspect of the nature of planning in India lies in the concept of the capitalist economy, in which the laws of capitalist development must inevitably make themselves felt (i e, the acceptance of private property in the means of production and the institutions based on this). It is often stated not only in government publications but in many other writings on the Indian economy and society that India has "opted" for a mixed economy, i e, the coexistence of the private sector with the publc sector. ${ }^{2}$ It is not made clear by these writers, however, by whom and how this type of economy was "opted" for.

In fact, it had been shown that as early as 1940, the majority of the joint stock companies operating in India were in the hands of a few British and Indian managing agency houses. ${ }^{3}$ It was these powerful economic interests that effectively controlled the industrial economy of India. During the Second World War, Indian industrialists were able to accumulate substantial amounts of capital. This was used in the years leading upto Independence to buy out some British managing agencies. By the time of Independence, therefore, 121 identifiable large economic interests, including 69 Indian groups (later to become famous as the "Big Business Groups") controlled Rs 350 crores of paid up capital. ${ }^{4}$ This amounted to about 73 per cent of the total paid up capital

*Madras Institute of Development Studies, Madras. 
in India at that time. Although there were, of course, many more corporate enterprises apparently independent of these powerful economic interests, their average size would not have been more than Rs 7 lakhs in terms of paid up capital. ${ }^{5}$

The point to be emphasised, therefore, is that while independance meant the transfer of "political" power to the Congress, it also meant the transfer of "economic" power to the big Indian industrialists and agricultural landlords. ${ }^{6}$ It is important to remember that while some of these industrialists had played a prominent role, directly or indirectly, in the national movement, they constituted the oligarchic blocin planning bodies. " It is thus unlikely that any other than a "mixed" pattern of economy could have been "opted" for, given the high degree of concentration of industrial assets in private hands, and the decision making power flowing from this. ${ }^{8}$ On the other hand, public enterprises in areas involving high risks and long gestation periods were required for the growth of enterprises controlled by large industrialists. Popular sentiment in favour of the public sector generated during pre-Independence debates was skilfully used to justify investments in such strategic industries. ${ }^{9}$

\section{Encouragement to Small Enterprises}

There was a socio-political as well as economic imperative for the conscious encouragement of small enterprises.

The high degree of concentration of capital in the Indian economy at the time of Independence led to a serious situation as far as the stability of the existing social order was concerned. Property distribution in India was, as figures for capital concentration show, extremely skewed, with only a minute fraction of the Indian population in ownership of industrial assets. Added to this was a situation where the country had achieved independence under the pressure of a mass national movement. Although never seriously challenging the legitimacy of institutions of private property, this had generated and disseminated democratic ideas, viewing unfavourably the existence of extreme concentrations of income and wealth. ${ }^{10}$ For the continuance and further development of the capitalist social order bequeathed by British colonialism to the leaders of the Congress-the major organised constituent of the national movement -it was essential, if not to distribute existing industrial and agricultural assets, at least to encourage the growth of numerous smaller property holders. ${ }^{11}$

The economic imperative facing the planners arose from the high degree of self-employment in the economy. According to the 1951 population census, over 58 per cent of the work force engaged in industry "neither employed any one nor did they work for anyone".12 If the mass of productive facilities already existing at the time of independence were to expand and grow, it was critical that the market for the goods which they produced should also grow. The goods produced in 
industrial establishments can be broadly classified into (1) those which are consumed directly; (2) those that are used in the manufacture of other articles (intermediate goods); and (3) the capital goods on which all these articles are manufactured. It is one of the laws of the development of economy that the market for intermediate goods and capital goods must increase at a faster rate than the market for consumer goods. ${ }^{13}$ To generate a fast growing market for capital goods and intermediate goods, it was necessary for the planners to encuurage a process of capital accumulation, leading to differentiation among the huge mass of self-employed persons.

Under the laws of capitalist competition, a small minority of these self-employed persons was to be expected to develop into a stratum of relatively small industrial entrepreneurs. The large majority would inevitably lose the little property they held, and enter the work force as wage workers. Processes in the agricultural sector similar to that of differentiation of the self-employed industrial workers described above were expected to take place simultaneously. ${ }^{14}$ Thus, both the sociopolitical imperative of the development of a small industrial capitalist stratum, and the economic imperative of the encouragement of small industrial enterprises pointed to the need for a set of official policy measures and institutions which would aid these processes. Both these requirements of capitalist economic development flowed out of the condition of the Indian economy at time. What is of interest in the Indian case, however, is that these requirements could be skillfully matched to the popular support for small industrialists and small enterprises which had been generated by democratic currents within the Congress itself in the pre-Independence period. Right wing and left wing elements within the Congress had debated the roles of the private and the public sectors, of large and small enterprises, and the content of post-Independence economic planning in the pre-Independence period. ${ }^{15}$

As a result of immediate post-Independence controversies, however, the plans of the left wing in the Congress for nationalisation of all large enterprises were diluted to measures for governmental regulation ${ }^{16}$ of initiation, expansion, and change of location of large industrial enterprises, the last named for the purpose of avoiding geographical concentration of industrial development. The 1951 Industrial Development and Regulation Act (IDRA) which was, and is, the chief administrative instrument of industrial planners, defined the size of the enterprise which would come under its purview, and also defined (by exclusion) enterprises which would be free of such regulations. This excluded sector came to be known officially as modern small enterprise sector.

In 1954, the office of the Development Commissioner, Small Scale Industries, was established in the Ministry of Industry in Delhi as the administrative agency responsible for planning and monitoring 
programmes for the development of small enterprises. In 1955, the National Small Industries Corporation was established to look after commercial programmes (such as the supply of machinery on hirepurchase, and the development of marketing channels) for small enterprises. In the subsequent years, each of the State Governments established its own corporation to develop small enteprises, in addition to the State Financial Corporations which provided financial assistance to small and medium enterprises.

At the present time, the government defines a small enterprise as one in which the cost to the owner of the plant and machinery installed is less than Rs 20 lakhs. In fact, from 1960, the Government has been defining small enterprises solely on the basis of the value of fixed capital, and later, in plant and equipment. Ostensibly because of the rising costs of plant and machinery due to inflation, the defining limit has been raised from time to time. This definition refers to what are known as modern small enterprises which can be found on the outskirts of most large cities, or on industrial estates. In addition, there are enterprises involved in handloom weaving, khadi, and some other traditional village occupations, which should also form part of a discussion of small enterprises.

\section{Concentration and Centralisation}

The institutions for the development of small enterprises which have been described are, therefore, the results of the economic and political requirements of a capitalist development strategy based on direct administrative intervention, on the one hand, and also the reflection of the democratic currents within the nationalist movement led by big capitalists, on the other. These institutions operate within the context of an economy subject to the laws of capitalist development, and it is to the effects of these laws that we now turn.

It has earlier been pointed out that under the pressure of capitalist competition, a process of differentiation takes place amongst the mass of small producers, leading to the emergence of a small propertied stratum and a large mass of wage workers. This process of dispossession on the one hand, and of property accumulation on the other, is an intrinsic part of the process of capitalist accumulation, or concentration, in the early stages of capitalist development. Simultaneously with this process of concentration of individual capitals, there is another process known as centralisation. ${ }^{17}$ This process is commonly observed in the form of merger of pre-existing enterprises, and involves the coming together of capitals already in existence. Larger and larger pools of capital are formed very swiftly by the process of centralisation which takes place particularly rapidly during periods of economic crisis when capitalist enterprises are "rationalised" or weeded out.

The stock exchanges in the country serve as another important means of centralisation; they help to pool capital held in various froms 
and even the savings of middle class sections of society, which are then utilised by the controllers of large joint stock companies.

Under the pressure of capitalist competition and the laws of concentration and centralisation, an enterprise must either grow in size continuously, or collapse sooner or later. It cannot remain stagnant in size. As the centralisation of capital increases, there is less and less room within the economy for new capitalist interests to operate. The result is that most of the small enterprises will fail to find a permanent place for themselves in the economy, and will be forced out of business sooner or later.

However, there can occasionally be short lived exceptions to this general rule. In the years following Independence, the shortage of foreign exchange led to restrictions on imports. In addition, encouraged by the brief thrust of the second five year plan strategy of self-reliant growth, many small enterprises did develop to fill in the gap left by import restrictions. Production of some articles of every day use such as kitchen utensils, cutlery, fountain pens, and plasticware began in small enterprises. Continuing demand for these products led to the growth of a certain number of these small enterprises.

\section{Economic Logic and Crisis of Small Enterprises}

Predictably, by the beginning of the third five year plan, and particularly after the economic crisis of the middle 1960s, the prospects for small enterprises have been increasingly unfavourable. Partly as a result of the inability to find "space" for new small enterprises in the economy, and partly as a result of meeting the pressure from big industrialists (which we shall discuss later), the Government has from the time of the third five year plan (1961-66) put some emphasis on the development of ancillaries amongst small enterprises. ${ }^{18}$ They were expected to survive on the basis of assured markets mainly provided by large enterprises.

The question that arises is how assured these markets really are Broadly speaking, a small enterprise can undertake three kinds of work, It may operate purely as a subcontractor on raw materials provided by the customer; it may manufacture an item to the long or short term order of another (usually larger) enterprise; or it may manufacture the item for direct sale on the market. Generally, both the subcontracting enterprises and those making a product to the order of other enterprises are known as ancillaries. In these cases, it can be seen that the small enterprise has no separate economic existence. It merely embodies a segment of the production process which has been separated from and apparently under the control of the large enterprise. The absence of possibilities of independent existence of these ancillary units makes them subject to a variely of pressures by their large customers. Particularly at times of recession in the economy, involving a credit squeeze, the larger enterprises attempt to improve their cash flow position by 
delaying payments. Cut throat competition between competing ancillaries drives the price of the goods often to the level of prime cost of production. The general existence of such conditions creates relationships of further dependence of the small entrepreneur on his big customer.

The situation is little, if at all, better for small enterprises making final products for the market. In the majority of cases, these enterprises face extreme competition from established large enterprises under the control of transnational monopolies and indigenous big business groups. ${ }^{19}$

It must be noted that there are no economies of large scale production to be gained ( $\mathrm{g}$, in the case of matches, toothpaste, and many other items) where the branded products of transnational and big Indian enterprises are houselold words. These large enterprises retain their dominant position by their control over raw material supplies, and especially by the enormous resources invested in the distribution and "marketing" networks extending even to the most remote village retailer. ${ }^{20}$ It must be emphasised, therefore, that the large size of these enterprises, and the very high rates of profit which they earn, are a result of their monopolistic position, and in no sense an indication of their efficiency of operation. A fraction of these profits are passed onto the "sole" retailers in the form of high discounts, thus ensuring that competing products of small entcrprises, even if they are cheaper, find few outlets. ${ }^{21}$

The fact that large foreign and indigenous industrial interests earn high profits by their operation, does not mean at all that they have no interest in the small enterprises field. As an unregulated sector, the small enterprises field allow them, through the development of benami ancillaries, to increase the capacity of their large enterprises beyond that licensed to them under IDRA. They are able to make use of the credit extended by the nationalised banks, under conditions where banks are eager to achieve bank lending norms to the "priority sector" of which small enterprises form a component. They can provide comfortable jobs to members of the extended families (which form the sociological core of the big business groups) and provide patronage to loyal ex-employees. ${ }^{22}$

Thus it is clear that the issue of aid to the small entrepreneur versus aid to the small enterprise is crucial both to the continuance of the programine and for the correct identification of beneficiaries.

\section{Struggle for Survival}

This infiltration of the small enterprise programme by established interests is an expression of the clash between two forces: the oligarchic ones (desiring merely the extension of the capitalist market for the means of production through the creation of smill enterprises) and the democratic ones desiring the safeguard of their income earning opportunities through the creation of small enterprises independent of 
monopolistic interests.

There have been a number of situations in the past which have shown attempts by oligarchic and democratic forces to gain control of the programme. Prominent amongst the democratic currents was the appointment of the A $R$ Bhat Committee to formulate legislation in support of the small enterprises programme. ${ }^{23}$ The small entrepreneur members of the committee suggested that a small entreprise be defined in relationship to the size of the total capital owned by an interest in all the enterprises controlled by it. In other words, they sought to remove the phenomenon of multiple ownership of small enterprises, and by extension, the owership of such enterprises by large industrial interests.

There was determined opposition to this from the majority of the committee drawn from the administration, and from among professional chartered accountants, both of whom represented big capitalist interests. Under the circumstances, the chairman himself (who, it must be noted, was not an entrepreneur himself, big or small) and the minority of the committee presented this suggestion in the form of a minute of dissent to the main report.

However, it is clear that the content of the legislation proposed in the main report potentially jeopardised big industrial interests. Although the report was submitted to the Government of India in 1972, it is still officially "under consideration". This incident illustrates the temporary assertion by democratic interests, expressed in the very formation of the Committee and in some of its recommendations. On the other hand, the Government's silence on the issue since 1972 shows the long term triumph of big industrial interests.

On another occasion, the democratic forces ensured that the official definition of the relationship between an ancillary unit and its large customer made it explicitly clear that the contract between the two was to be fair to both parties. ${ }^{24}$ However, this was an unrealistic expectation, given the present day circumstance. Through the expedient of refusing to acknowledge enterprises which were in fact serving as their ancillaries, the attempt of the democratic forces, though worth nothing, was sidetracked.

Finally, mention may be made of a recent move to modify IDRA in order to bring the concept of reservation of itemes for exclusive production by small enterprises onto a basis acceptable to the courts. ${ }^{25}$ This follows a decision of the Bombay High Court which held that the administrative order reserving items could not be sustained under legal scrutiny. ${ }^{26}$ These are all examples of attempts by democratic forces to strengthen the small cnterprises development programme in the interest of the small entrepreneur.

On the other hand, large industrial interests have attempted by all possible means to ensure that the government programme, as an institution, continues to serve their long term interests. They, however, 
thwart the operation of the provisions which assist small individual entrepreneurs to develop into a competing body, or a stratum independdent of them. It is precisely this opposition that manifests big capitalist domination responsible for the collapse of many small enterprises.

Apart from the so-called modern small enterprises, there are two other kinds of small enterprises which require consideration. The first of these consists of enterprises in the textile industry using handlooms and powerlooms. These enterprises which are concentrated specifically in Maharashtra and Tamil Nadu, are peculiar in that they represent production processes of a traditional nature which have been modified selectively. They are major providers of employment, particularly in Tamil Nadu and their products need to be protected from the competition of the products of the large scale integrated textile enterprises.

The second kind of small enterprises which, in general, is more of a traditional technological nature lies under the purview of the Khadi and Village Industries Commission (KVIC). In its search to generate income earning opportunities on a large scale in the rural areas, the Commission's activities are particularly important in drawing women of the Scheduled Castes into regular paid employment. Although the KVIC has managed, through its programme, to cover a negligible fraction of these sections, its scheme for the collection of indigenous seeds, for example, constitutes efforts worthy of much greater public support. Here again, the programmes are not likely to make a headway unless the activities of large foreign and indigenously owned enterprises are effectively curbed.27

\section{Conclusion}

Small entrepreneurs are aware that they are in a situation in which the logic of an economy dominated by large industrial interests provides them with little room to survive, let alone grow. ${ }^{28}$ In addition, they are subject to harrassment at the hands of the agencies of the government as frequently as an ordinary citizen. The link or collusion of interests between big industrialists and government agencies is at once apparent to the small enterpreneur. He can see the differential treatment accorded to big industrialists on the one hand, and to himself on the other, even when the same rules apply to both. As their very survival is at stake, the small entrepreneur stratum is vitally interested in the removal of the domination of large industrial interests as it exists today.

Specific measures such as excise reductions on the products of small enterprises and effective reservation of items for production exclusively in small enterprises, can ease the burden of the small entrepreneur. However, a crucial step is to ensure that only the deserving benefits from these concessions, that is, to weed out the real from the benami small entrepreneur. ${ }^{29}$ The associations of small enterprises are 
currently the hotbeds of corruption and political opportunism. However, they do form, in an embryonic manner, the vehicles of policing the small enterprises development programme generally. They may also serve as an appropriate channel for conducting a dialogue between small entrepreneurs and other sections of society fighting for democratic advance.

Without implicating them in any way, I am grateful to Kishore Theckedath, and to Meena Radhakrishan for their comments on the formulations in an earlier draft.

1 This is very clearly elaborated by E M S Namboodripad in his Indian Planning in Crisis, Trivandrum, Chintha Publishers, 1974. See especially pp 24-25.

2 Shirokov, for instance, talks in non-class and mystical terms of "India's conception of industrialisation". See G K Shirokov, Industrialisation of India, Moscow, Progress Publishers, 1973, p 10.

3 Wadia and Merchant describe the situation on the basis of figures provided in Asoka Mehta's pamphlets. See P A Wadia and K T Merchant, Our Economic Problems, Bombay, New Book Co, 1943.

4 G K Shirokov, op cit, p 49.

5 The paid up capital of all joint stock companies in India was Rs 479.5 crores (number 21,853) on 31 March 1947, and Rs 569.6 crores (number 22,675) on 31 March 1948. If we take the 1947 figure and assume that each of the 121 groups controlled 50 companies on the average, then the average size of the remaining companies can be obtained by simple arithmetic. For the data see, R K Nigam and N C Chaudhuri, The Corporate Sector in India: A Factual Presentation of Long and Short-Term Trends, New Delhi, Government of India, Ministry of Commerce and Industry, Department of Company Law Administration, Research and Statistics Division, 1961.

6 Sardar Vallabhai Patel was (together with Bhulabhai Desai) specifically mentioned by G D Birla as one who was "fighting against socialism". In turn, Patel commended the first finance minister, Shanmukham Chetty, to business leaders as "one of their own". In fact, until Patel's death in 1950, both the finance and industry ministries functioned under his control.

G D Birla's commendation (in a letter to Walchand Hirachand) is quoted in R K Ray, Industrialisation in India, Delhi, Oxford University Press, 1979, p 326. Patel's commendation was reported in FICCI's Golden Jubilee Special Supplement to the Times of India (New Delhi), 23 April 1977, p 1. Patel's power was made obvious by his letters, collected and edited by Durga Das, Vol 6, Ahmedahad, Navjivan, 1972, p 536 .

7 In all the collective efforts at planning in the pre-independence period in which industrialists were included in the planning body, the reports were either agnostic or hostile to nationalisation of existing enterprises. These efforts included setting up of the Congress' National Planning Committee (appointed in 1938), the Reconstruction Committee of the Viceroy's Executive Council (formed in 1941), the efforts of the Government of India's Planning and Development Department (established in 1944), the "Bombay" or "Tata-Birla" Plan, 1944, and the Advisory Planning Board's report, 1947. Significantly, the All India Congress Committee's Economic Programmes Committee appointed in November 1947 had no direct or indirect representation of big industrial interests It recommended nationalisation in a forthright way, but this line of thinking (let alone action) was quickly brought to heel by the A I C C.

8 The degree of this power is indicated by the Government of India's apparent naivete in asking the industrialists to accept nationalisation, and then retreating to some kind of "compromise", leaving the industrialists in full control See the 
report of the proceedings of the Conference on Industrial Development in India, New Delhi, Ministry of Industry and Supply, 1948.

9 One of Asoka Mehta's pamphlets provides a graphic illustration of the way in which pro-public sector sentiments were aroused. "The annual profits of the Tata Iron and Steel Company equal the total revenues of the Government of Bihar. And it is just one of the Tata concerns. We demand democratic control over the finances of the Government of Bihar. Shall we let the industries remain under the unchecked control of their oligarchs?" Quoted in Wadia and Merchant $o p$ cit, p 482. By implication any investment undertaken by the Government actually extended democratic control over the economy as a whole, ard was not merely a pre-requisite for such democratic control.

10 The Constitution, with all its limitations, is perhaps the best index of this. See E M S Namboodripad, "The Republican Constitution in the Struggle for Socialism", in Selected Writings: Vol 1, Calcutta, National Book Agency, 1982, pp 316-336.

11 In 1950, the Fiscal Commission had stressed the fact that as a source of employment to "middle class" people, the social importance of small enterprises was "out of all proportion to their relative strength in the industrial sector". It went on to suggest that the Government should take special interest in their promotion and development. Report of the Fiscal Commission 1949-50, Volume 1, New Delhi, Government of India, 1950, p 112. With the help of a Ford Foundation assisted team, the Government of India established the Office of the Development Commissioner for Small Scale Industries (see below), and a network of related institutions in 1954. Although the programmes spoke in terms of small scale enterprises, a senior administrator closely concerned with the programme since its inception had made it clear that the concern was with small scale entrepreneurs. See the letter written by P C Alexander, then Developnent Commissioner (Small Scale Industries) to all Directorates of Industry and Small Industries Service Institutes, quoted in S K Goyal et al, Small Scale Sector and Big Business: Studies in National Development, Number 2, New Delhi, IJPA, 1984, p 69 . In 1961 C Tylor Wood, Economic Affairs Minister in the United States Embassy in New Delhi wrote a "memorandum of conversation" to the then U S Ambassador, $\mathrm{J} \mathrm{K} \mathrm{Galbraith.} \mathrm{In} \mathrm{it} \mathrm{he} \mathrm{mentioned} \mathrm{a} \mathrm{meeting} \mathrm{held} \mathrm{on} 20$ June 1961 in Delhi in which discussions were held with Indian officials who shared his concern that the small enterprises development programme "was one of the most effective means of helping to develop a pluralistic society and a self-reliant middle class in India". Present at the meeting were B Venkatappiah, Deputy Governor of the Reserve Bank of India, K C Mittra, Bombay Manager at the RBI, C Ensminger, Ford Foundation Representative in India, and Tylor Wood himself. (File on Assistance to the Indian Small Industries Development Organisation, Office of the Ford Foundation, New Delhi).

12 For the data and definitions see, for instance, Census, paper No. 1 of 1960: Economic Tables of Reorganised States-1951 Census, Delhi, Registrar General of India, 1961.

13 For an elaboration of this point, see V' I Lenin, "The Development of Capitalism in Russia", Collected works, Volume III Moscow, Progress Publisher, 1960, pp $51-58$.

14 In this case Government policies were oriented towards the transformation of fcudal landlords into capitalist landlords, and the creation of a rich peasant stratum. Thus the bulk of middle peasants and the entire poor peasants were expected to be dispossessed and enter the agricultural or industrial work force. The rnots of the crisis in India devclopment lie preciscly in this stategy.

15 See references given in 7 , above.

16 The process of reconciling "middle class radicalism" with the strategy favoured by the big industrialists was set in motion by the AICC when, following the strategy mentioned in 7 above, it constituted a committee chaired by Jawaharlal 
Nehru. This committee was supposed to work out the detailed implications flowing from the Congress Economic Programmes Committee's Report and the pronoucedly status quoist Industiral Policy Resolution of 1948.

17 The distinction between the processes and their interconnection is analysed in K Marx, Capital, Vol 1, Ch 25.

18 See Government of India, Ministry of Commerce and Industry, Report of the Working Group on Small Scale Industries: Programme of Work for the Third Five Year Plan, New Delhi, 1960.

19 The clearest expression of this is the ubiquitous infringement of the policy reserving items for exclusive production in the small scale sector by transnational and indigenous big enterprises. See S K Goyal, et al, op cit.

20 A company like Hindustan Lever, for instance, has 4000 retail stockists whose turnover varies from Rs 25,000 to Rs 2 crors per annum. These stockists supply 300,000 retailers. In addition, the company has "satellite or van markets" which service remote markets, whether from "Patiala in the Punjab or Tiruvalla in Kerala". T Thomas, "Distribution of Essential Commodities", Speech at Annual General Meeting of Hindustan Lever Limited, 20 June 1975.

21 Thomas offers an ingenious rationale for the marketing practices of large corporations by arguing that without the investment in sales promotion by these corporations, products would lie with retail traders longer. These costs of storage would then be passed onto the customer through higher margins. T Thomas, $o p$ cit. As a matter of fact, heavy advertising expenditure and extensive distribution networks serve basically as barriers to entry to competing products.

22 For exhaustive documentation, see S K Goyal, et al, op cit.

23 See Government of India, Ministry of Industrial Development, Report of the Committee for Drafting Legislation for Small Scale Industries, 1972, (Mimeo).

24 In the official definition it is stated that an ancillary unit should not be "a subsidiary to or controlled by any large units in regard to the negotiations of contracts for supply of its goods to any large unit". Various guidelines to regulate the relationship between ancillary and parent unit have been specified.

25 See, for example, Economic Times (Bombay), 14 January 1984.

26 The case concerned a large scale unit, Vindhya Paper Mills us Union of India, Indian Security Press and Gandhi Brothers Private Limited. Vindhya Paper Mills had been given a license to produce "speciality papers". Gandhi Brothers, who were supplying low grade stamp paper to the Security Press represented to the Ministry of Industries that the license could not be used by Vindhya Paper Mills to produce high grade stamip paper, as this was a reserved item. Justice Bharucha held that Section 29 B (1) of the IDRA could not be used to reserve items and that all orders reserving items for exclusive production would have to be withdrawn. See, Financial Express (Madras), 10 February 1983.

27 The cases of Balsara vs Colgate - Palmolive, and many others, are well known as cases where small enterprises face extreme competition in products which are supposedly reserved for the small scale sector. However, the crux of the problem in this case, as in many others, while never possible to document, is well known even to senior officials of the Goverment of India. For instance, a member of the staff of Hindustan Lever told the Chief of the Small Enterprises Division in the Planning Commission that his company welcomed the efforts of the Division to set up small soap manufacturing units. For once these units had become established and "created a market" for soap, Hindustan Lever would move in, and by underselling the small entreprenuer for some time, take over the cost free "market" for soap.

28 Even brief discussions with small entrepreneurs will produce reactions such as the following by a machine tool manufacturer in Madras: "All this talk about growth is bunkum! As soon as you try to grow they (the banks and other official agencies operating as Organisations) try everything possible to pull you down!" 
29 A further distinction within the group of "real" small entrepreneurs has to be made. The importance of distinguishing between the "huckster" section and the "working" section as pointed out by Lenin in the case of the peasantry has to be borne in mind. This, as Lenin warned, is a very difficult but a crucial political task. Lenin's remarks are in his "Economics and Politics in the Era of the Dictatorship of the Proletariat", Collected Works, Vol XXX, Progress Publishers Moscow, 1965, p 113. 